\title{
What is New in Pharmacologic Therapy for Cardiac Resuscitation?
}

\author{
John Somberg, ${ }^{\mathrm{a}, \mathrm{c}}$, Janos Molnar ${ }^{\mathrm{b}}$
}

\begin{abstract}
Antiarrhythmic therapy can be a critical component of cardiac resuscitation. Therapies in this area have seen little advance in the last decade. Bretylium, a very old drug, has been reintroduced for ventricular tachycardia/ventricular fibrillation (VT/VF) therapy. There are still important questions to be addressed with bretylium: when to administer (first- or second-line) and at which dose. These questions and the development of newer agents will be areas of future research.
\end{abstract}

Keywords: Cardiac resuscitation; Antiarrhythmic; Bretylium

\section{Introduction}

The pharmacologic therapy for cardiac resuscitation has not changed dramatically in many years. The last major change was in the guidelines, turning from lidocaine as a first-line antiarrhythmic to the preferred use of amiodarone. Three studies supported the first-line use of amiodarone for the treatment of ventricular tachycardia (VT), or ventricular fibrillation (VF) cardiac arrest. A large study by Dorian and colleagues showed amiodarone superior to lidocaine [1]. One smaller study supported the superiority of intravenous (IV) amiodarone over lidocaine in patients with incessant VT or VF [2]. However it is often forgotten that in a randomized study by Kowey and colleagues [3] another agent, bretylium, was as effective as amiodarone in treating VT/VF.

\section{Bretylium: A Reintroduction}

The use of bretylium has been forgotten because the drug has not been available since 1999 due to shortages in supplies of the chemical substance. The drug substance is difficult to make

Manuscript submitted March 30, 2020, accepted April 9, 2020

aAmerican Institute of Therapeutics, Lake Bluff, IL, USA

bRoslyn Franklin University of Health Sciences, Chicago, IL, USA

${ }^{\mathrm{c} C o r r e s p o n d i n g ~ A u t h o r: ~ J o h n ~ S o m b e r g, ~ A m e r i c a n ~ I n s t i t u t e ~ o f ~ T h e r a p e u t i c s, ~}$

Lake Bluff, IL, USA. Email: John_Somberg@rush.edu

doi: https://doi.org/10.14740/cr1058 and the requirements for the manufacture of IV products became stricter, both factors combining to make bretylium unavailable in the USA. For these reasons, bretylium was removed from the advanced cardiac life support (ACLS) guidelines in 2000 [4].

However, recently (December 2019) bretylium became available again in the USA. This availability raises the question of how bretylium is to be employed in the pharmacotherapy of cardiac resuscitation. Bretylium was first developed as an antihypertensive agent. Marvin Bacaner, while studying cardiac metabolism and the effect of antiadrenergic drugs by performing cardiac biopsies in vivo in animal hearts found that the dogs in his study did not develop VF when treated with bretylium. He stopped his cardiac metabolism studies and went on to study the effect of bretylium [5] as an antiarrhythmic agent.

Bretylium as an antiarrhythmic agent has some unique properties. The drug is known to deplete vesicular stores of catecholamines [6] causing a "chemical like" sympathectomy. Additionally, bretylium causes an increase in the effective refractory period [7] of heart tissue and increases the electrical homogeneity of areas of infarcted as well as normal tissue $[8,9]$. The increased homogeneity is believed to have an antiarrhythmic effect by reducing the substrate for VT that depends on a reentrant pathway for VT or VF [10]. Electrical heterogeneity of the myocardium, a requisite for VF substrate is modified by bretylium [11]. Bretylium in more recent studies has been found to inhibit the potassium rectifier channel (IKr) [12] and thus prolongs the action potential duration (APD) [13]. This APD prolongation is a mechanism of action similar to amiodarone. Bretylium is effective in increasing the VF threshold in animal models [14-16], as well as in man [17]. For these reasons, bretylium is an effective treatment for VF and VT $[5,18]$. Bretylium does have similar properties to amiodarone, while being an antifibrillatory agent. Interestingly, bretylium is the only drug ever approved by the US Food and Drug Administration (FDA) specifically to treat, as well as prevent the occurrence of VF [19].

Bretylium has one major side effect that is derived from its antiadrenergic action. It can cause hypotension, especially orthostatic hypotension. In the randomized trial by Kowey and associates, bretylium caused more hypotension than amiodarone, though hypotension is a problem with both drugs [3]. Hypotension caused by amiodarone or bretylium can be treated with fluid (colloid or crystaloid). The dose Bacaner et al first studied and advocated was $30 \mathrm{mg} / \mathrm{kg}$ body weight. At the dose 
they recommended $(30 \mathrm{mg} / \mathrm{kg}$ ) hypotension was not a significant problem. The $5 \mathrm{mg} / \mathrm{kg}$ dose that is recommended in the product label chosen by FDA is reported to cause a significant incidence of hypotension. Studies are needed to determine if Bacaner's observation that a higher dose of bretylium is more effective and causes less hypotension than the recommended 5 $\mathrm{mg} / \mathrm{kg}$ [9] dose.

Along with the issue of dose-related hypotension, there is also the consideration of dose-related efficacy. Bacaner and colleagues evaluate a higher dose of bretylium than what is currently approved [9]. It was Bacaner's belief that the $30 \mathrm{mg} /$ $\mathrm{kg}$ dose of bretylium was more efficacious than the lower dose approved. Thus, any study evaluating the hypothesis of less hypotension at a higher dose should also evaluate the potential increased efficacy using higher doses of bretylium.

Given the long period of time that has elapsed since bretylium has been employed, the question arises as to how bretylium should be reintroduced into clinical practice. It seems prudent to have bretylium available and to employ the recommended doses in the label to treat VT and VF that is not responsive first to shock and then amiodarone. Patients who have not responded well to amiodarone in prior VT/VF episodes, patients on amiodarone who develop VT/VF and patients in persistent VF despite maximum shock therapy should be considered for first-line bretylium. While we do not have data, it seems reasonable to consider bretylium for patients in electrical storm and those patients with electrical storm secondary to defibrillator implant. Bretylium appears uniquely effective in patients in $\mathrm{VF}$, raising the VF threshold.

\section{Antiarrhythmic Drugs in Resuscitation}

Currently, there is considerable controversy surrounding the usefulness of antiarrhythmic therapy. Mcleod and colleagues reported a network meta-analysis, and found no drug improved the rate of hospital discharge in patients who underwent a cardiac arrest [20]. They reported that lidocaine and amiodarone were not effective in improving survival to hospital discharge. This is an often-stated criticism of antiarrhythmic therapy that the drugs do not prolong life. However, this criticism fails to take into account the multi-factorial issues related to discharge survival, or to overall survival. Antiarrhythmic drugs are employed to terminate VT or VF, or to facilitate shock-resistant termination of VT/VF but do not address the underlying cause of the VT/VF, and thus may not affect discharge or outcome. Antiarrhythmic agents do not address ischemia, myocardial infarction damage to heart muscle, heart failure, electrical heterogeneity, brain ischemia, or a host of other causes of acute life-threatening arrhythmias. The antiarrhythmic drugs can terminate an arrhythmia, but the underlying condition that precipitated the arrhythmia often is not affected and these conditions lead to the patient's mortality.

Additionally, VT/VF arrest leads to significant hypoxia that can severely damage the brain, heart and other critical organs. The length of time that the patient is hypotensive or pulseless directly relates (inversely) to survival. Those efforts to accelerate response times to treat arrhythmias and therapies to treat hypoxic organ damage are critical. Antiarrhythmic drugs are only one link in the chain of survival. However, if one cannot terminate the arrhythmia then there is no hope for patient survival. Antiarrhythmic agents' success is the initial requisite for patient survival. Metrics such as survival to discharge, 6- or 12-months survival depend on a multitude of factors.

There are reports that recently showed that lidocaine is as effective, or more effective than amiodarone [21, 22]. However, those who have been called to treat resistant arrhythmias in clinical situations and had extensive experience prior to the availability of amiodarone are aware of the inefficacy of lidocaine as compared to amiodarone. It may be that in the studies and meta-analysis, the prolonged response times for out-ofhospital arrest makes a distinction between the agents in terms of arrhythmia termination efficacy impossible.

Early studies have shown amiodarone to be superior to lidocaine $[1,2]$, and Bretylium to be equally effective as amiodarone [3]. Bretylium increased survival to hospital admission in two studies with bretylium compared to control therapy $[23,24]$, and when combined in a meta-analysis [25] significantly improved survival to admission, but not to hospital discharge, as is the case with other antiarrhythmics [20].

\section{Future Research Directions}

A future study of clinical import would be to compare a higher bretylium dose of $30 \mathrm{mg} / \mathrm{kg}$ to the effects of amiodarone in all VT/VF patients, or in amiodarone-resistant VT/VF population. It would also be informative to randomize patients to 5 vs. $30 \mathrm{mg} / \mathrm{kg}$ bretylium. Until we have more information on this old drug, using bretylium as a second-line therapy seems appropriate.

To improve patient survival, we need to find ways to reduce the time to resuscitation. In very high-risk groups, implantation of a defibrillator has markedly improved survival. The defibrillator treats the arrhythmia with shock almost instantly and thus short periods of time to VT/VF termination clearly prolongs life [26-28]. However, we cannot treat effectively those we do not identify as high risk, and we cannot implant a defibrillator in the majority of patients making this approach untenable. We need new approaches to identify atrisk patients for VT/VF. Additionally, therapies to protect the brain and heart are needed that can enhance survival. Cooling therapy has not succeeded [29], as well as various pharmacologic agents to modify ischemic injury [30-32]. Research in these areas is very much needed to help in the quest to improve survival.

\section{Acknowledgments}

None to declare.

\section{Financial Disclosure}

John Somberg has a financial interest in Academic Pharmaceu- 
ticals, which developed bretylium and transferred ownership of the NDA to Pharmaceutical International (Pii).

\section{Conflict of Interest}

None to declare.

\section{Author Contributions}

Both authors contributed to writing the manuscript.

\section{Data Availability}

The authors declare that data supporting the findings of this study are available within the article.

\section{References}

1. Dorian P, Cass D, Schwartz B, Cooper R, Gelaznikas R, Barr A. Amiodarone as compared with lidocaine for shock-resistant ventricular fibrillation. N Engl J Med. 2002;346(12):884-890.

2. Somberg JC, Bailin SJ, Haffajee CI, Paladino WP, Kerin NZ, Bridges D, Timar S, et al. Intravenous lidocaine versus intravenous amiodarone (in a new aqueous formulation) for incessant ventricular tachycardia. Am J Cardiol. 2002;90(8):853-859.

3. Kowey PR, Levine JH, Herre JM, Pacifico A, Lindsay BD, Plumb VJ, Janosik DL, et al. Randomized, double-blind comparison of intravenous amiodarone and bretylium in the treatment of patients with recurrent, hemodynamically destabilizing ventricular tachycardia or fibrillation. The Intravenous Amiodarone Multicenter Investigators Group. Circulation. 1995;92(11):3255-3263.

4. Guidelines 2000 for Cardiopulmonary Resuscitation and Emergency Cardiovascular Care. Part 6: advanced cardiovascular life support: section 1: Introduction to ACLS 2000: overview of recommended changes in ACLS from the guidelines 2000 conference. The American Heart Association in collaboration with the International Liaison Committee on Resuscitation. Circulation. 2000;102(8 Suppl):I86-89.

5. Bacaner MB. Quantitiative comparison of bretylium with other antifibrillatory drugs. Am J Cardiol. 1968;21(4):504-512.

6. Mizgala HF. Newer Drugs in the Treatment of Hypertension. Can Med Assoc J. 1965;92:918-922.

7. Heissenbuttel RH, Bigger JT, Jr. Bretylium tosylate: a newly available antiarrhythmic drug for ventricular arrhythmias. Ann Intern Med. 1979;91(2):229-238.

8. Torresani J. Bretylium tosylate in patients with acute myocardial infarction. Am J Cardiol. 1984;54(2):20A-25A.

9. Bacaner M, Brietenbucher J, LaBree J. Prevention of ventricular fibrillation, acute myocardial infarction (myocar- dial necrosis), heart failure, and mortality by bretylium: is ischemic heart disease primarily adrenergic cardiovascular disease? Am J Ther. 2004;11(5):366-411.

10. Sasyniuk BI. Symposium on the management of ventricular dysrhythmias. Concept of reentry versus automaticity. Am J Cardiol. 1984;54(2):1A-6A.

11. Bacaner MB. Treatment of ventricular fibrillation and other acute arrhythmias with bretylium tosylate. Am J Cardiol. 1968;21(4):530-543.

12. Bacaner MB, Clay JR, Shrier A, Brochu RM. Potassium channel blockade: A mechanism for suppressing ventricular fibrillation. Proc Natl Acad Sci U S A. 1986;83(7):2223-2227.

13. Swissa M, Qu Z, Ohara T, Lee MH, Lin SF, Garfinkel A, Karagueuzian HS, et al. Action potential duration restitution and ventricular fibrillation due to rapid focal excitation. Am J Physiol Heart Circ Physiol. 2002;282(5):H1915-1923.

14. Euler DE, Scanlon PJ. Mechanism of the effect of bretylium on the ventricular fibrillation threshold in dogs. Am J Cardiol. 1985;55(11):1396-1401.

15. Holland K, Patterson E, Lucchesi BR. Prevention of ventricular fibrillation by bretylium in a conscious canine model of sudden coronary death. Am Heart J. 1983;105(5):711-717.

16. Anderson JL, Patterson E, Conlon M, Pasyk S, Pitt B, Lucchesi BR. Kinetics of antifibrillatory effects of bretylium: correlation with myocardial drug concentrations. Am J Cardiol. 1980;46(4):583-592.

17. Bacaner M. Experimental and clinical effects of bretylium tosylate on ventricular fibrillation, arrhythmias, and heart block. Geriatrics. 1971;26(1):132-148.

18. Cohen HC, Gozo EG, Jr., Langendorf R, Kaplan BM, Chan A, Pick A, Glick G. Response of resistant ventricular tachycardia to bretylium. Relation to site of ectopic focus and location of myocardial disease. Circulation. 1973;47(2):331-340.

19. BRETYLIUM TOSYLATE injection-Product specific label. Available at: https://dailymed.nlm.nih.gov/daily$\mathrm{med} /$ drugInfo.cfm?setid=b5b9b1de-d819-4e49-ac0b05b29033df1c.

20. McLeod SL, Brignardello-Petersen R, Worster A, You J, Iansavichene A, Guyatt G, Cheskes S. Comparative effectiveness of antiarrhythmics for out-of-hospital cardiac arrest: A systematic review and network meta-analysis. Resuscitation. 2017;121:90-97.

21. Kudenchuk PJ, Brown SP, Daya M, Rea T, Nichol G, Morrison LJ, Leroux B, et al. Amiodarone, lidocaine, or placebo in out-of-hospital cardiac arrest. N Engl J Med. 2016;374(18):1711-1722.

22. Salcido DD, Schmicker RH, Kime N, Buick JE, Cheskes S, Grunau B, Zellner S, et al. Effects of intra-resuscitation antiarrhythmic administration on rearrest occurrence and intra-resuscitation ECG characteristics in the ROC ALPS trial. Resuscitation. 2018;129:6-12.

23. Nowak RM, Bodnar TJ, Dronen S, Gentzkow G, Tomlanovich MC. Bretylium tosylate as initial treatment for cardiopulmonary arrest: randomized comparison with placebo. Ann Emerg Med. 1981;10(8):404-407. 
24. Stang JM, Washington SE, Barnes SA, Dutko HJ, Cheney BD, Easter CR, O'Hara JT, et al. Treatment of prehospital refractory ventricular fibrillation with bretylium tosylate. Ann Emerg Med. 1984;13(4):234-236.

25. Chowdhury A, Fernandes B, Melhuish TM, White LD. Antiarrhythmics in cardiac arrest: a systematic review and meta-analysis. Heart Lung Circ. 2018;27(3):280-290.

26. Moss AJ, Madit II. MADIT-II: substudies and their implications. Card Electrophysiol Rev. 2003;7(4):430-433.

27. Zareba W, Steinberg JS, McNitt S, Daubert JP, Piotrowicz $\mathrm{K}$, Moss AJ, Investigators MI. Implantable cardioverterdefibrillator therapy and risk of congestive heart failure or death in MADIT II patients with atrial fibrillation. Heart Rhythm. 2006;3(6):631-637.

28. Al-Khatib SM, Hellkamp A, Bardy GH, Hammill S, Hall WJ, Mark DB, Anstrom KJ, et al. Survival of patients receiving a primary prevention implantable cardioverterdefibrillator in clinical practice vs clinical trials. JAMA.
2013;309(1):55-62.

29. Kalra R, Arora G, Patel N, Doshi R, Berra L, Arora P, Bajaj NS. Targeted temperature management after cardiac arrest: systematic review and meta-analyses. Anesth Analg. 2018;126(3):867-875.

30. Piot C, Croisille P, Staat P, Thibault H, Rioufol G, Mewton $\mathrm{N}$, Elbelghiti R, et al. Effect of cyclosporine on reperfusion injury in acute myocardial infarction. N Engl J Med. 2008;359(5):473-481.

31. Sharma V, Bell RM, Yellon DM. Targeting reperfusion injury in acute myocardial infarction: a review of reperfusion injury pharmacotherapy. Expert Opin Pharmacother. 2012;13(8):1153-1175.

32. Schwartz Longacre L, Kloner RA, Arai AE, Baines CP, Bolli R, Braunwald E, Downey J, et al. New horizons in cardioprotection: recommendations from the $2010 \mathrm{Na}-$ tional Heart, Lung, and Blood Institute Workshop. Circulation. 2011;124(10):1172-1179. 